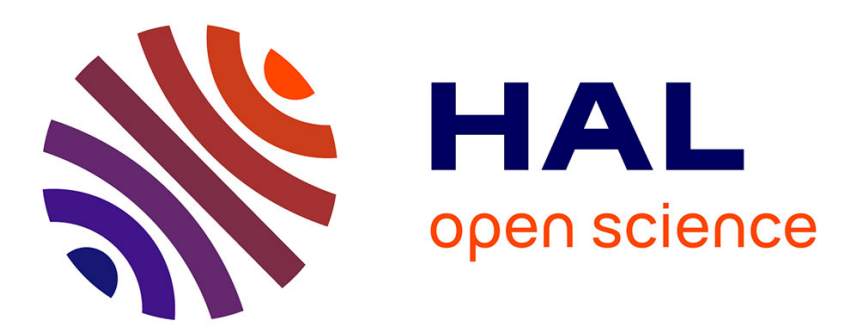

\title{
Amorphous Oxide Films of the Bi2O3-Fe2O3-PbTiO3 System Coexisting Ferromagnetism and Ferroelectricity Prepared by Gel-Coating
}

T. Fujii, T. Wada, Y. Tokunaga, K. Kawahito, M. Inoue, A. Kajima, B. Jeyadevan, T. Tohji

\section{To cite this version:}

T. Fujii, T. Wada, Y. Tokunaga, K. Kawahito, M. Inoue, et al.. Amorphous Oxide Films of the Bi2O3Fe2O3-PbTiO3 System Coexisting Ferromagnetism and Ferroelectricity Prepared by Gel-Coating. Journal de Physique IV Proceedings, 1997, 07 (C1), pp.C1-493-C1-494. 10.1051/jp4:19971201 . jpa00254852

\section{HAL Id: jpa-00254852 https://hal.science/jpa-00254852}

Submitted on 1 Jan 1997

HAL is a multi-disciplinary open access archive for the deposit and dissemination of scientific research documents, whether they are published or not. The documents may come from teaching and research institutions in France or abroad, or from public or private research centers.
L'archive ouverte pluridisciplinaire HAL, est destinée au dépôt et à la diffusion de documents scientifiques de niveau recherche, publiés ou non, émanant des établissements d'enseignement et de recherche français ou étrangers, des laboratoires publics ou privés. 


\title{
Amorphous Oxide Films of the $\mathrm{Bi}_{2} \mathrm{O}_{3}-\mathrm{Fe}_{2} \mathrm{O}_{3}-\mathrm{PbTiO}_{3}$ System Coexisting Ferromagnetism and Ferroelectricity Prepared by Gel-Coating
}

\author{
T. Fujii, T. Wada, Y. Tokunaga, K. Kawahito, M. Inoue, A. Kajima*, B. Jeyadevan** and T. Tohji** \\ Department of Electrical and Electronic Engineering, Toyohashi University of Technology, 1-1 Hibari- \\ ga-oka, Tempaku-cho, Toyohashi 441, Japan \\ * Department of Electrical Engineering, Kitakyushu National College of Technology, 5-20-1, Shii, \\ Kokura-Minami-ku, Kitakyushu 803, Japan \\ ** Department of Resources Engineering, Faculty of Engineering, Tohoku University, Aoba, Aramaki, \\ Aoba-ku, Sendai 980-77, Japan
}

\begin{abstract}
Magnetic and diclectric properties of films with the ternary oxide systcm $\mathrm{Bi}_{2} \mathrm{O}_{3}-\mathrm{Fc}_{2} \mathrm{O}_{3}-\mathrm{PbTiO}_{3}$ prepared by coating gel-solutions synthesized by the glycol-gel process on either glass plates or low resistivity Si-wafers were investigated. It was found that films with the $\mathrm{Fe}_{2} \mathrm{O}_{3}$-molar concentration around $70 \%$ exhibit ferromagnetic as well as ferroelectric behaviors simultaneously above room temperarure retaining amorphous state fron $x$-ray diffraction even after annealed at $700^{\circ} \mathrm{C}$ in air. The microstructure of the films was examined by EXAFS and was confirmed to be in a strongly disordered state. These pronounced properties are supposed to arise from a sort of excessively frustrated spin glasses.
\end{abstract}

\section{INTRODUCTION}

We have previously reported that amorphous films of the ternary oxide system $\mathrm{Bi}_{2} \mathrm{O}_{3}-\mathrm{Fe}_{2} \mathrm{O}_{3}-\mathrm{ABO}_{3}\left(\mathrm{ABO}_{3}: \mathrm{BaTiO}_{3}, \mathrm{PbTiO}_{3}, \mathrm{PbZrO}_{3}\right.$ etc. $)$ prepared by if-sputtering in an argon and oxygen mixed gas atmosphere exhibit ferromagnetism and ferroelectricity simultaneously well above room temperarure in a narrow composition range of the $\mathrm{Fe}_{2} \mathrm{O}_{3}$ concentration near $70 \%$ after annealed above $600^{\circ} \mathrm{C}$ in air[1-4]. However, the films after annealing involved a lot of pinholes, which hinder measurements of dielectric properties from planar capacitors due to short circuit across the electrodes, so that reliable data of ferroelectricity could not be obtained. To overcome this difficulty, we have tried to prepare the same system films by coating gel-solution by a spinning-disc on either Corning \#7059 glass plates or low resistivity Si-wafers and calcined at temperatures up to $800^{\circ} \mathrm{C}$ in air. By this technique, optically flat films without microcracks and pinholes could successfully be prepared even after the films were subject to annealing at high temperatures. In this article, we describe ferromagnetic and ferroelectric properties of gelcoated films and found that both properties are supposed to be a correlated phenomenon from their variations of annealing temperature and compositional dependence.

\section{FILM PREPARATION}

As for liquid precursor of the sol-gel method, we adopted the "glycol gel process" compounded by bismuth (III) nitrate $\left(\mathrm{Bi}\left(\mathrm{NO}_{3}\right)_{3} 5 \mathrm{H}_{2} \mathrm{O}\right)$, iron (III) nitrate $\left(\mathrm{Fe}\left(\mathrm{NO}_{3}\right)_{3} 9 \mathrm{H}_{2} \mathrm{O}\right)$, lead (II) nitrate $\left(\mathrm{Pb}\left(\mathrm{NO}_{3}\right)_{2}\right)$ and titanium (IV) isoproxide $\left(\mathrm{Ti}\left(\mathrm{OC}_{3} \mathrm{H}_{7}\right)_{4}\right)$ dissolved in ethylene glycol $\left(\mathrm{HOCH}_{2} \mathrm{CH}_{2} \mathrm{OH}\right)$. The sol-gel reaction proceeds by heating the solution at $80^{\circ} \mathrm{C}$ in a nitrogen flow. After the viscosity of the gel reached about $60 \mathrm{cp}$, the solution was cooled to room temperature and coated on substrates [Corning \#7059 glass plates and/or low resistivity $(\rho=0.1-0.01 \Omega \mathrm{cm}) \mathrm{Si}$ wafers] by using a spinning disc. The coated gel was dried at $50^{\circ} \mathrm{C}$ and preheated at temperatures $T_{p a}=250-400^{\circ} \mathrm{C}$ for $20 \mathrm{~min}$. in air to evacuate bydrocarbons and $\mathrm{NO}_{\mathrm{x}}$ impurites contained in the gel. The thickness per one-run coating was limited to be about $0.1 \mu \mathrm{m}$ to obtain crack free films. This process was repeated several times and the film samples were finally

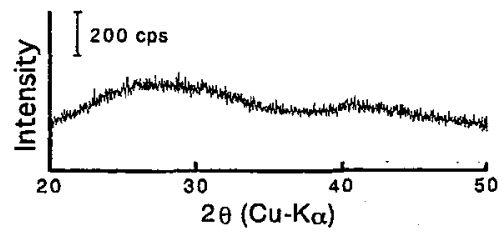

Figure 1: XRD pattern of a $0.16 \mathrm{Bi}_{2} \mathrm{O}_{3}-0.74 \mathrm{Fe}_{2} \mathrm{O}_{3}$ $-0.1 \mathrm{PbTiO}_{3}$ film annealed at $\mathrm{T}_{\mathrm{a}}=700^{\circ} \mathrm{C}$.

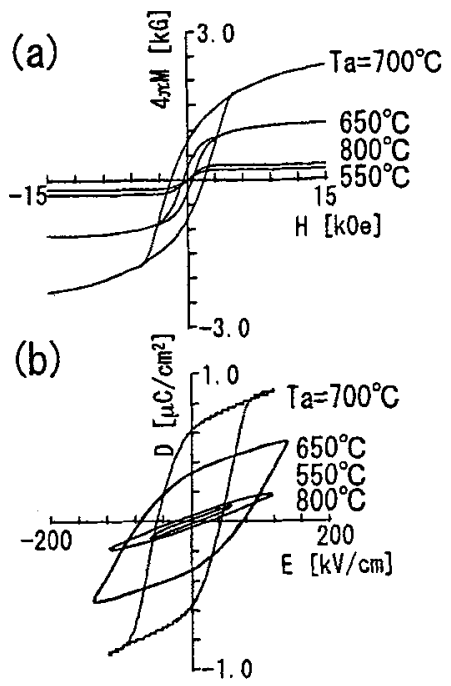

Flgure 2: Magnetic hystercsis loops(a) and diclectric hystcresis loops(b) of the film shown in Fig.1 for calcination temperature $T_{a}$. 
obtained by rapid annealing utilizing a halogen-lamp furnace at temperatures $T_{a}=500-800^{\circ} \mathrm{C}$ for $10 \mathrm{~min}$. Rapid elevating and cooling temperatures were found be useful to prevent formation of pinholes and crystalline precipitates. The crystallographic character was examined by $\mathrm{x}$-ray diffractometry (XRD) with $\mathrm{Cu}-\mathrm{K} \alpha$ radiation and extended $\mathrm{x}$-ray absorption fine structure (EXAFS) measurement. The film composition was determined by electron-probe microanalysis (EPMA) and its deviation from the starting solutions was found to remain within the range $\pm 2 \%$. The magnetic and dielectric properties were measured by a vibratingsample-magnetometer (VSM) and Sawyer-Tower method operated at $f=60$ $\mathrm{Hz}$, respectively.

\section{RESULTS}

We have prepared films with a wide variety of compositions in the $\mathrm{Bi}_{2} \mathrm{O}_{3}$ $\mathrm{Fe}_{2} \mathrm{O}_{3}-\mathrm{PbTiO}_{3}$ system and found that the compositions with large room temperature saturation magnetization exceeding $4 \pi \mathrm{M}_{\mathrm{s}}=1 \mathrm{kG}$ are in a narrow $\mathrm{Fe}_{2} \mathrm{O}_{3}$-concentration range around 0.7 after calcined above $600^{\circ} \mathrm{C}$. It should be noted that such films are $x$-ray amorphous. An example of $\mathrm{XRD}$ patterns is shown in Fig. 1, which is the film with $0.16 \mathrm{Bi}_{2} \mathrm{O}_{3}$ $0.74 \mathrm{Fe}_{2} \mathrm{O}_{3}-0.1 \mathrm{PbTiO}_{3}$ in composition annealed at $\mathrm{T}_{\mathrm{a}}=700^{\circ} \mathrm{C}$, which exhibits the maximum $4 \pi \mathrm{M}_{\mathrm{s}}(=2.2 \mathrm{kG})$ attained in the present study. The $\mathrm{T}_{\mathrm{a}}$-evolution of magnetic hysteresis loops of the film shown in Fig.1 is drawn in Fig.2(a). $4 \pi \mathrm{M}_{\mathrm{S}}$ begins to appear at about $\mathrm{T}_{\mathrm{a}}=500^{\circ} \mathrm{C}$, it increases with $T_{a}$ and takes a maximum at $T_{a}=700^{\circ} \mathrm{C}$ and then decreases rapidly with higher $\mathrm{T}_{\mathrm{a}}$, where precipitates of para-or antiferromagnetic phases such as $\mathrm{PbO} \cdot 2 \mathrm{Fe}_{2} \mathrm{O}_{3}$ and $\alpha-\mathrm{Fe}_{2} \mathrm{O}_{3}$ appear. This result suggests that amorphous state is essential for establishing ferromagnetic character. Figure $2(b)$ is the $T_{a}$-evolution of dielectric hysteresis loops of the same sample. As seen in the figures, there have common features in appearance of magnetic and dielectric hysteresis loops, inferring that both properties originates from correlated origins. Such common features are also seen in the compositional dependence. Figures $3(a)$ and (b) are the variations of the magnetic quantities $\left(4 \pi \mathrm{M}_{\mathrm{s}}\right.$ and magnetic coercivity $\mathrm{H}_{\mathrm{c}}$ ) and the dielectric quantities (the saturation electric polarization $D_{S}$ and electric coercivity $\mathrm{E}_{\mathrm{C}}$ ), respectively, against the $\mathrm{Fe}_{2} \mathrm{O}_{3}$-concentration $\mathbf{x}$ for the series of films with $x \mathrm{Fe}_{2} \mathrm{O}_{3}-(1-\mathrm{x})\left(0.33 \mathrm{Bi}_{2} \mathrm{O}_{3}-0.67 \mathrm{PbTiO}_{3}\right)$. This result also suggests that ferromagnetism and ferroelectricity coexist simultaneously at room temperature in amorphous oxide films.There have been reports on amorphous oxide materials which exhibit ferromagnetic behaviors at high temperature, where the ferromagnetic origin of these samples is considered to be caused by ferrimagnet nanoclusters. In order to see the microstructure of our samples, the absorption edge of iron in EXAFS spectra was measured. Figure 4 is Fourier transform of EXAFS spectrum of the film used in Fig.1 together with that of lead hexaferrite
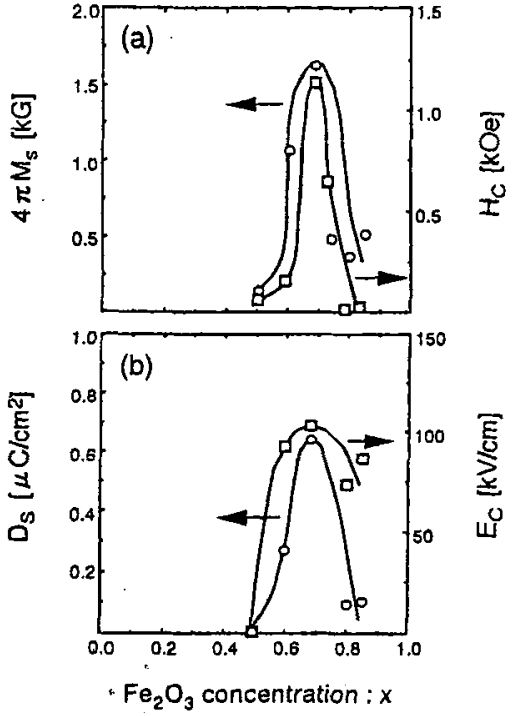

Figure 3: Variations of nugnetic quantities(a) and dielectric quantities(b) as a function of the $\mathrm{Fc}_{2} \mathrm{O}_{3}$ concentration $x$, where $T_{2}=700^{\circ} \mathrm{C}$.

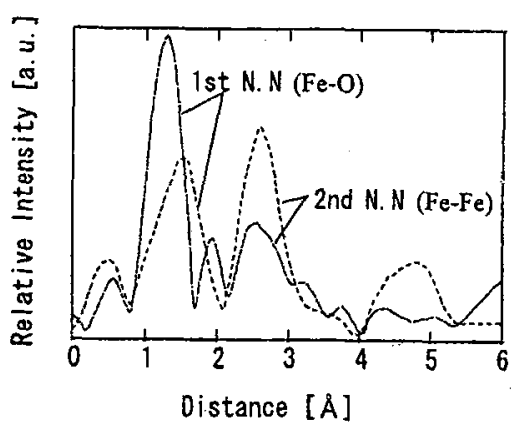

Figure 4: Fourier transform of EXAFS of the film shown in Fig.1. The dotted curve: lead-hexaferrite. $\left(\mathrm{PbO} \cdot 6 \mathrm{Fe}_{2} \mathrm{O}_{3}, \mathrm{PbM}\right)$ powder drawn by the dotted line, which is the most possible material candidate giving rise to ferrimagnetism in the present system. From the figure, the sorounding coordination of iron ions is considerably different from that of $\mathrm{PbM}$ powder: The 1st nearest neighbour is assigned to be Fe-O bonding. From inverse Fourier-transform of the 1st nearest neighbour peak, the average bond distance of the film is estimated to be $182 \AA$, which is noticeably small compared to that of $\mathrm{PbM}$ powder $(1.98 \AA)$, and long range order is not clearly recognized, suggesting that our films are in a highly disordered state. Thus it is likely that the peculiar properties coexisting on ferromagnetic and ferroelectric behaviors of our amorphous oxide films originate from a certain kind of highly frustrated spin-glasses.

\section{References}

[1] T.Fujii, S.Jinzenji, Y.Asahara, A.Kajima and T.Shinjo, J.Appl.Phys.,64 (1988) 5434-5436.

[2] A.Kajima, T.Kaneda, H.Ito, T.Fujii, I.Okamoto, T.Kimura and K.Ohdan, J.Appl.Phys., 69 (1991) 3663-3669.

[3] A.Kajima, T.Kaneda, H.Ito, T.Fujii and I.Okanoto, J.Appl.Phys., 70 (1991) 3760-3764.

[4] A.Kajima, K.Ideta, K.Yamashita, T.Fujii, H.Nii and I.Fujii, "Ferroelectric behaviors of rf-sputtered amorphouslike $\mathrm{Bi}_{2} \mathrm{O}_{3}-\mathrm{Fe}_{2} \mathrm{O}_{3}-\mathrm{PbTi}(\mathrm{Zr}) \mathrm{O}_{3}$ films" Proceedings of the 6th International Conference on Ferrites (ICF6), T.Yamaguchi and M.Abe Eds. (Jpn. Soc. Powder and Powder Metallurgy, Tokyo 1992) pp 452-455. 